IRA-International Journal of Applied Sciences

ISSN 2455-4499; Vol.04, Issue 02 (2016)

Institute of Research Advances

Pg. no. 296-304

http://research-advances.org/index.php/IRAJAS

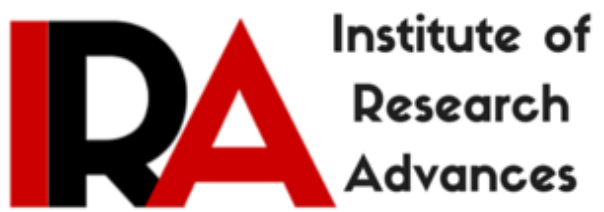

\title{
Cytotoxicity of Fractions Derived from Crude Water Soluble Extract (CWSE) of Momordica charantia (Linn) Leaves on Lung, Cervical and Breast Cancer Cells
}

\author{
1a,1b, 2,4 Adeola F. Ehigie, ${ }^{1 \text { a }}$ Peng Wei, ${ }^{2}$ Leonard O. Ehigie, ${ }^{3}$ Samuel A. Odediran,

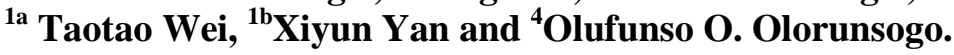 \\ ${ }^{1 a}$ National Laboratory of Biomacromolecules, Institute of Biophysics, Chinese Academy \\ of Sciences, Beijing 100101, China. \\ ${ }^{1 b}$ Key Laboratory of Protein and Peptide Pharmaceuticals, Institute of Biophysics, \\ Chinese Academy of Sciences, Beijing 100101, China. \\ ${ }^{2}$ Department of Biochemistry, Ladoke Akintola University of Technology, Ogbomoso, \\ Oyo State, Nigeria. \\ ${ }^{3}$ Department of Pharmacognosy, Obafemi Awolowo University, Ile-Ife, Osun State, \\ Nigeria. \\ ${ }^{4}$ Laboratories for Biomembrane Research and Biotechnology, Biochemistry Department, \\ College of Medicine, University of Ibadan, Ibadan, Nigeria.
}

Type of Review: Peer Reviewed.

DOI: http://dx.doi.org/10.21013/jas.v4.n2.p10

\section{How to cite this paper:}

Ehigie, A., Wei, P., Ehigie, L., Odediran, S., Wei, T., Yan, X., \& Olorunsogo, O. (2016). Cytotoxicity of fractions derived from Crude Water Soluble Extract (CWSE) of Momordica charantia (Linn) Leaves on Lung, cervical and Breast cancer cells. IRA-International Journal of Applied Sciences, 4(2), 296-304. doi:http://dx.doi.org/10.21013/jas.v4.n2.p10

(C) Institute of Research Advances

(cc)) BY-No

This work is licensed under a Creative Commons Attribution-Non Commercial 4.0 International License subject to proper citation to the publication source of the work.

Disclaimer: The scholarly papers as reviewed and published by the Institute of Research Advances (IRA) are the views and opinions of their respective authors and are not the views or opinions of the IRA. The IRA disclaims of any harm or loss caused due to the published content to any party.

Corresponding Author: Dr Leonard O. Ehigie, Department of Biochemistry, Ladoke Akintola University of Technology, Ogbomoso, Nigeria. E-mail: lehigie@lautech.edu.ng Tel: +2348032069229 . 


\section{ABSTRACT}

The in vitro cytotoxicity of five fractions derived from the crude water-soluble extract (CWSE) of Momordica charantia, a known medicinal herb was tested on four cancer cell models; MDA-MB 436 and 231 (breast cancer cell lines), HeLa (Cervical cancer cell lines) and A549 (Lung cancer cell lines). Nhexane (D4) < Dichloromethane (D5) < Ethyl acetate (D3) < Butanol (D2) < Aqeous (D6) fractions, all obtained via solvent partitioning in their order of increasing polarity were administered at varied concentrations $(50,75,100,125,150$ and $200 \mu \mathrm{g} / \mathrm{mL})$ for $24 \mathrm{~h}$.

Cell viability was detected using the MTT assay. Cells treated with the Butanol and Aqueos fractions respectively showed survival rates as high as $96.11 \%$ and $85.75 \%$ for MDA-MB 231; 93.59\% and 88.28\% for MDA-MB 436; $101.62 \%$ and $96.76 \%$ for HeLa and $89.55 \%$ and $81.40 \%$ for A549 even at $200 \mu \mathrm{g} / \mathrm{mL}$, the highest considered concentration.

Whereas, at tested concentrations, cells treated with the $N$-hexane, Dichloromethane and Ethyl acetate fractions showed marked cytotoxic effects with the Inhibitory concentration $\left(I_{50}\right)$ ranging between $100 \mu \mathrm{g} / \mathrm{mL}$ and $125 \mu \mathrm{g} / \mathrm{mL}$. We also observed that the ethylacetate fraction displayed the highest cytotoxicity having its approximate $I_{50}$ at $100 \mu \mathrm{g} / \mathrm{mL}$, especially for MDA-MB 231 ( 51\%), HeLa ( 54\%) and $A 549$ ( 43\%). The percentage viability for $M D A-M B 436$ at $100 \mu \mathrm{g} / \mathrm{mL}$ is about $64.2 \%$, albeit at $125 \mu \mathrm{g} / \mathrm{mL}$ percentage viability dropped to $34.7 \%$

This paper may provide cytological evidence for the inhibitory effect of Momordica charantia on certain cancer cell proliferation.

Keywords: Momordica charantia, cancer cell lines, cytotoxicity, MTT assay and crude water-soluble extract (CWSE).

\section{Introduction}

Evidence abound now of the important role played by popular medicinal plants in the treatment and management of ailments (Tauseef and Shahabuddin, 2013). One of the most feared ailments of our time is cancer which in 2012 accounted for up to 8.2 million deaths of the total 14.1 million cases reported (Ferlay et al., 2013). The medicinal plant Momordica charantia (MC) has been named as one of such potent medicinal plants especially in relation to its usefulness in the treatment and management of cancers (Kubola and Siriamornpun, 2008). Quite a number of literatures have affirmed the antiproliferative effects of the plant on cancer cell lines (Lee-Huang et al., 2000; Yasui et al., 2005; Ray, et al., 2010; Fang et al., 2012). In our Lab, a number of preliminary tests carried out on this plant suggest it may be a potent inducer of apoptosis; the death a cell caused by its own self (Odewusi et al., 2010; Ehigie et al, 2013). Many types of cancers, numbering more than 100 different types have been named. In 2008, approximately 12.7 million cancers were diagnosed (excluding non-melanoma skin cancers and other non-invasive cancers) (Jemal et al., 2011) and in 2010 nearly 7.98 million people died (Lozano et al., 2012). Cancers as a group account for approximately $13 \%$ of all deaths each year with the most common being: lung cancer (1.4 million deaths), stomach cancer (740,000 deaths), liver cancer (700,000 deaths), colorectal cancer $(610,000$ deaths), and breast cancer $(460,000$ deaths) (WHO on "Cancer", 2010) This makes invasive cancer the leading cause of death in the developed world and the second leading cause of death in the developing world (Jemal et al., 2011). Over half of these cases occur in the developing world (Jemal et al., 2011). The Hallmarks of cancer include uncontrolled cell division, evasion of apoptosis, non-dependence on growth regulation, angiogenesis, immortality and invasion and metastasis. Carcinogenesis is the actual formation of a cancer, whereby normal cells are transformed into cancer cells. The process is characterized by a progression of changes at the cellular, genetic and epigenetic level 
that ultimately reprogram a cell to undergo uncontrolled cell division, thereby forming a malignant mass (Fearon and Vogelstein, 1990). We now know that some herbs may have inhibitory effects on the proliferation of cancer cell lines (Chen and King, 2005) a much desired weapon in the war against cancer cell growth. A greater understanding of the pivotal events associated with carcinogenesis will facilitate the use of natural products/medicinal plants as a key strategy to prevent cancer and initiate cancer cell death. Indeed, experimental evidence indicates that phytochemicals can modulate the complex multistage process of carcinogenesis at each of the three recognized stages of initiaton, promotion and malignant progression (Chen and King, 2005). Working on the premise that MC is a potent pro-apoptotic agent (Ehigie et al, 2013) and most likely possessive of anti-proliferative properties, we assayed to determine its likely anti-cancer properties. Hence, the experiments leading to this publication which exhibits our findings on the cytotoxicity of fractions derived from the CWSE of MC in Breast, Lung and Cervical cancer cell lines.

\section{Materials and methods}

\section{Chemicals}

The culture media and fetal bovine serum were purchased from Hyclone (Logan, UT, USA). The CCK8 cell counting kit was from Dojindo Laboratories (Kumamoto, Japan). Cell-culture Petri dishes were from BD Biosciences (San Jose, CA, USA). N-hexane, Dichloromethane, Ethyl acetate and Butanol were obtained from BDH chemicals Ltd, (Poole UK). All other reagents were manufactured in China and of analytical grade.

\section{Plant material}

Fresh, healthy leaves of Momordica charantia were collected from the Botanical gardens of the Obafemi Awolowo University, Ile- Ife Campus, Nigeria and authenticated at the Faculty of Pharmacognosy Herbarium of the same Institution with the plant herbarium No. FPL-1783. The petioles were separated, weighed, rinsed with clean water, drained and air -dried. A total of $5.4 \mathrm{~kg}$ was pulverised using a manual blender and subsequently soaked in 9.0 litres of water. It was left for 12 hours at room temperature with occasional agitation. The macerate was filtered, concentrated in vacuo at $65^{\circ} \mathrm{C}$ to small volume using the rotary evaporator before being freeze-dried to obtain a powdery extract. The yield was about $4.87 \%$ of the raw material.

\section{Fractionation of the extract}

The powdery extract, was subsequently adsorbed on silica gel (ratio of 1:1) with little methanol, transferred to a Buchner funnel, where it was successively eluted under vacuum using solvents of different polarities to obtain n-hexane (D4), dichloromethane (D5), ethyl acetate (D3), butanol (D2) and aqueous (D6) fractions respectively. The solvents of elution were only switched when it was clear to daylight and by TLC. Each fractions obtained during partitioning was subjected to concentration in-vacuo and later freeze dried to obtain powdery samples. After freeze drying, the different fractions were preserved at low temperature $\left(4^{\circ} \mathrm{C}\right)$.

\section{Cell culture}

The human breast cancer cells MDA-MB-231, MDA-MB-436, the human cervical cancer cells HeLa and the human lung cancer cells A549 were all obtained from American Type Culture Collection (ATCC; Manassas, VA, USA) and were cultured under conditions recommended by ATCC.

Cell viability assessment using the 3- (4, 5-Dimethyl thiazol-2-yl)-2,5-Diphenyltetrazolium bromide (MTT) Assay

The cytotoxicity induced by the five fractions of the crude water-soluble extract of Momordica charantia was determined using the MTT Assay, which is based on the reduction of water-soluble tetrazolium salt 
by mitochondrial reductases of metabolically active cells. Briefly, cells already plated in 96-well plates were treated with $50-200 \mu \mathrm{g} / \mathrm{ml}$ of the five fractions for $24 \mathrm{~h}$ at $37{ }^{\circ} \mathrm{C}$ in a humidified incubator at an atmosphere of $95 \%$ air and $5 \% \mathrm{CO}_{2}$. After drug treatment, the old culture medium is removed and the cells were incubated with $100 \mu \mathrm{l}$ of $10 \%$ MTT solution for $2 \mathrm{~h}$ at $37^{\circ} \mathrm{C}$, after which the solution was replaced with DMSO, which solubilized the formazan crystals formed by MTT to give a purple /violet solution whose absorbance was measured at $490 \mathrm{~nm}$ using a microplate Reader (Thermo Labsystems) Spectrophotometer. Cell viability is expressed as percentage of MTT reduction.

\section{Data analysis}

The difference between the control groups and the experimental groups were determined using the oneway Analysis of Variance (ANOVA) and Student's t-test. P-values less than 0.05 were considered as significant. All data were analyzed using Microsoft Office Excel, 2007 and GraphPad Prism Computer software packages.

\section{Results}

The percentage cell viabilities of the Model cell lines (MDA-MB 231\&436, HeLa and A549) treated with the five fractions (D2-D6) of CWSE of MC at different $(50-200 \mu \mathrm{g} / \mathrm{ml})$ concentrations over a period of 24 $\mathrm{h}$ were obtained. In Figure 1, the percentage cell viability of MDA-MB 231 cells treated with D2 and D6 were as high as $96.11 \%$ and $85.75 \%$ respectively at $200 \mu \mathrm{g} / \mathrm{ml}$, the highest tested concentration, rending these two fractions non cytotoxic. However, for D3, D4, and D5 more than 95\% of cells died at this same concentration. D3 being the most potent fraction, presenting only $50.56 \%$ cell viability at $100 \mu \mathrm{g} / \mathrm{ml}$, $33.61 \%$ viability at $125 \mu \mathrm{g} / \mathrm{ml}$ and $20.66 \%$ at $150 \mu \mathrm{g} / \mathrm{ml}$ compared with D4 and D5 which cells' viability were as high as $96.54 \%$ and $77.16 \%$ at $100 \mu \mathrm{g} / \mathrm{ml}, 65.85 \%$ and $45.63 \%$ at $125 \mu \mathrm{g} / \mathrm{ml}$ and $58.70 \%$ and $39.01 \%$ at $150 \mu \mathrm{g} / \mathrm{ml}$ respectively. In Figure 2, assessing the effect of MC on MDA-MB 436; the percentage cell viability for D2 and D6 were as high as $93.59 \%$ and $88.28 \%$ respectively at $200 \mu \mathrm{g} / \mathrm{ml}$, the highest tested concentration, rending them non cytotoxic, while at least $85 \%$ of cells died at this same concentration when treated with D3, D4 and D5, with D3 being the most potent extract presenting $64.19 \%$ cell viability at $100 \mu \mathrm{g} / \mathrm{ml}, 34.71 \%$ viability at $125 \mu \mathrm{g} / \mathrm{ml}$ and only $12.29 \%$ viability at $150 \mu \mathrm{g} / \mathrm{ml}$ compared with D4 and D5 which cells' viability were as high as $74.36 \%$ and $69.75 \%$ at $100 \mu \mathrm{g} / \mathrm{ml}$, $46.08 \%$ and $57.04 \%$ at $125 \mu \mathrm{g} / \mathrm{ml}$ and $22.42 \%$ and $43.00 \%$ at $150 \mu \mathrm{g} / \mathrm{ml}$ respectively. A similar trend was observed for the Lung cancer (A549) cells (Figure 3) as D2- and D4-treated cells had percentage cell viability as high as $89.55 \%$ and $81.40 \%$ respectively at $200 \mu \mathrm{g} / \mathrm{ml}$, the highest tested concentration whereas, up to about 95\% cells died in the D3-treated group while for D4 and D5 about 75\% of cells died at this same concentration. D3 being the most potent extract presenting only $42.76 \%$ cell viability at $100 \mu \mathrm{g} / \mathrm{ml}, 31.64 \%$ viability at $125 \mu \mathrm{g} / \mathrm{ml}$ and $21.53 \%$ at $150 \mu \mathrm{g} / \mathrm{ml}$ compared with D4 and D5 which cells' viability were $49.15 \%$ and $53.71 \%$ at $100 \mu \mathrm{g} / \mathrm{ml}, 31.60 \%$ and $45.62 \%$ at $125 \mu \mathrm{g} / \mathrm{ml}$ and $24.58 \%$ and $32.80 \%$ at $150 \mu \mathrm{g} / \mathrm{ml}$ respectively. For the HeLa cells (Figure 4), percentage cell viability were as high as $101.62 \%$ and $96.76 \%$ for D2- and D4- treated cells, respectively at $200 \mu \mathrm{g} / \mathrm{ml}$. However, for D3, D4, and D5 more than $90 \%$ of cells died at this same concentration. D3, the most potent extract presented only $54.10 \%$ viability at $100 \mu \mathrm{g} / \mathrm{ml}, 38.58 \%$ viability at $125 \mu \mathrm{g} / \mathrm{ml}$ and $27.55 \%$ at $150 \mu \mathrm{g} / \mathrm{ml}$ compared with D4 and D5 which cells' viability were as high as $72.65 \%$ and $85.38 \%$ at $100 \mu \mathrm{g} / \mathrm{ml}, 66.00 \%$ and $48.22 \%$ at $125 \mu \mathrm{g} / \mathrm{ml}$ and $43.47 \%$ and $42.05 \%$ at $150 \mu \mathrm{g} / \mathrm{ml}$ respectively.

\section{Discussion}

Plant-derived herbal medicines have been used for a long time in several countries. Anticancer activity is one among all the effects been reported by studies in vitro using natural herb extracts (Kandaswami et al., 2005; Cheng et al., 2010). M. charantia, also called bitter melon, is a popular vegetable of great medicinal value. It has been named as one of such potent medicinal plants especially in relation to its usefulness in the treatment and management of cancers (Kubola and Siriamornpun, 2008). For instance, Kuguacin $\mathbf{J}$ and momorcharins, phytochemicals derived from the plant were effective against human 
prostate cancer (Xiong et al., 2009; Pitchakarn et al., 2011). These findings suggest that $M$. charantia has great potential as a health food or a source for new drug development.

In the current study, we determined the cytotoxicity of five fractions derived from the crude water-soluble extract of M. charantia on four selected cancer cell lines at varying concentrations.

The observed effects of three of the fractions obtained from the crude water soluble extract of Momordica charantia depict that these fractions are potent cytotoxic agents against the selected cancer cells. For example, the Ethylacetate fraction (D3) which is believed to be rich in flavonoids (Xu and Chang, 2007) exhibited consistently high cytotoxicity against all cancer cell lines, even at the least tested concentration of $50 \mu \mathrm{g} / \mathrm{ml}$. Likewise D4 and D5 albeit, at a lower toxicity level. On the contrary, D2 and D6, two of the fractions obtained from the extract showed no significant cytotoxic effects, as concentration of viable cells were still very high (93.59\% and $88.28 \%$ respectively) even at the highest concentration of $200 \mu \mathrm{g} / \mathrm{ml}$.

Thus, D3 was adjudged the most potent fraction presenting a cell viability of less than $10 \%$ in all cell lines at the highest tested concentration.

We have thus been able to show that though the medicinal plant of interest has cytotoxicity against cancer cells, the solvents in which the plant is extracted play a key part in its effectiveness in the killing cancer cells. Also, the concentrations at which these fractions of MC are administered matter. Generally, the higher the concentration, the more cytotoxic the fractions become. Our observation is further underscored by the finding that MC has anti- leukemia and antiviral activities ( $\mathrm{Ng}$ et al., 1994), inhibits the growth of several cancer cell lines, including prostate adenocarcinoma, (Clafin et al., 1978), human colon cancer (Caco-2 cells) (Yasui, et al., 2005), the highly metastatic breast cancer cell lines MDA 231(Lee-Huang et al., 2000).

Conclusively, we submit that the effective drugs are D3, D4, D5. There are differences in the sensitivity of the different cell lines to the different drugs for example, MDA-MB 436 cells differ slightly in their sensitivity to the tested drugs as seen in the cell viability assay results; while D3 at $100 \mu \mathrm{g} / \mathrm{mL}$ showed percentage cell viability as low as $50.57 \%, 42.76 \%$ and $54.10 \%$ for MDA-MB 231, A549 and HeLa respectively, the percentage cell viability at this concentration for MDA-MB 436 was as high as 64.19\%, short of the standard $\mathrm{IC}_{50}$. We also deduced that the most efficacious drug concentration for the fractions are between 100 and $125 \mu \mathrm{g} / \mathrm{ml}$ while the most potent of the fractions is D3. 


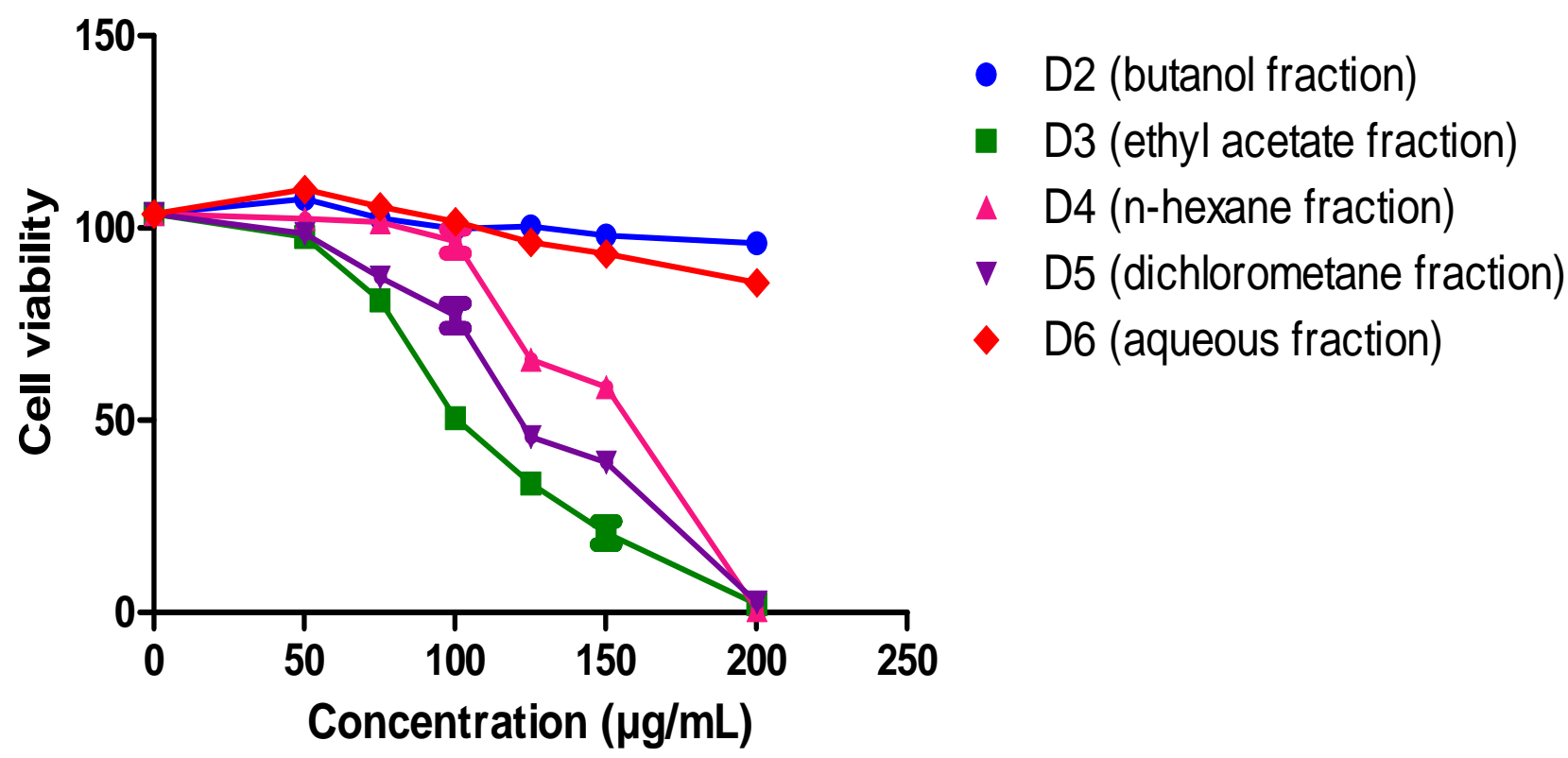

Figure 1: The cell viability of MDA-MB 231 cells at different $(50-200 \mu \mathrm{g} / \mathrm{ml})$ concentrations of the five fractions (D2-D6) at $24 \mathrm{~h}$. Data are presented as mean \pm SEM ( $n=5$ per group). Level of significance was taken at $* \mathrm{p}<0.05$

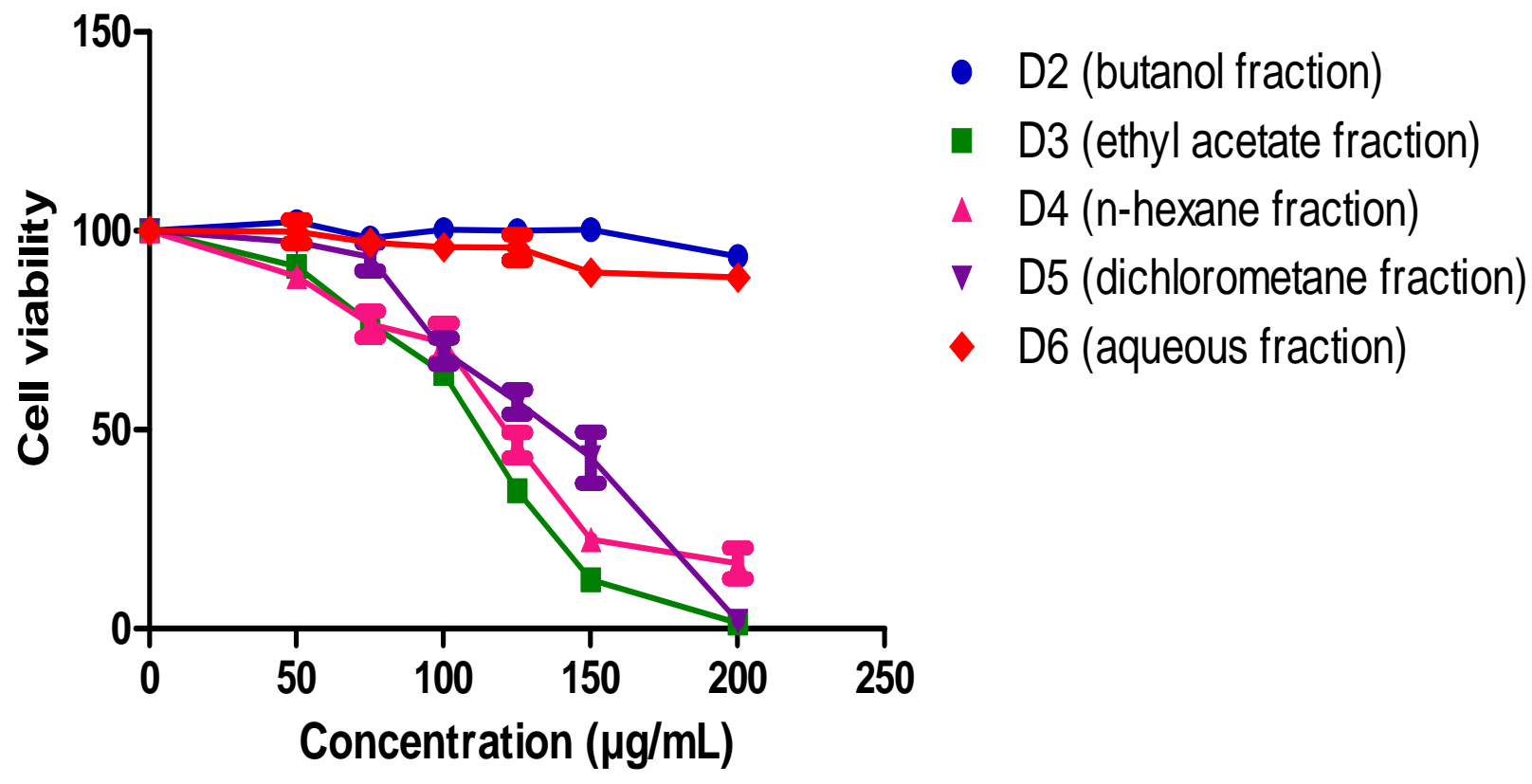

Figure 2: The cell viability of MDA-MB 436 cells at different $(50-200 \mu \mathrm{g} / \mathrm{ml})$ concentrations of the five fractions (D2-D6) at $24 \mathrm{~h}$. Data are presented as mean \pm SEM ( $\mathrm{n}=5$ per group). Level of significance was taken at $* \mathrm{p}<0.05$ 


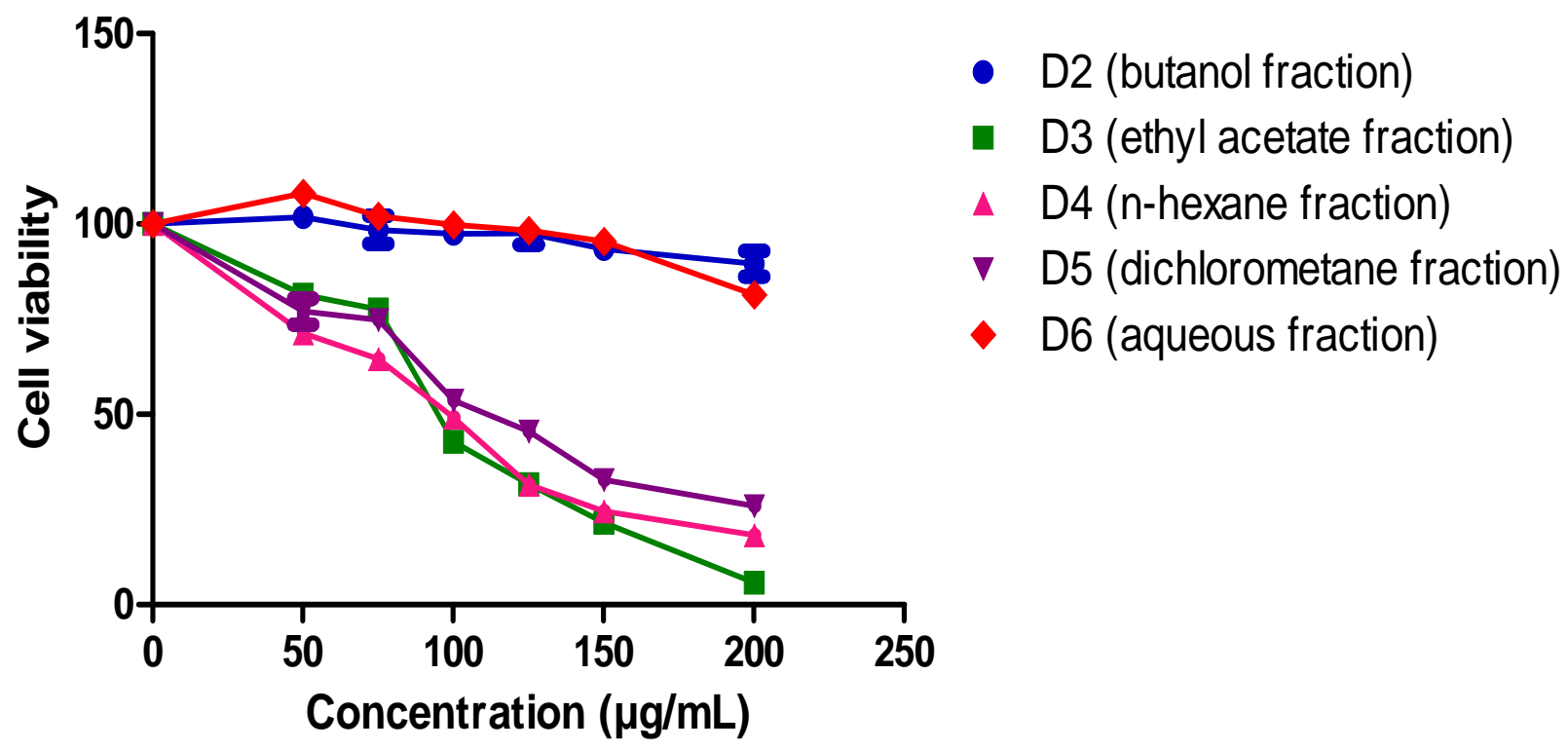

Figure 3: The cell viability of A549 cells at different $(50-200 \mu \mathrm{g} / \mathrm{ml})$ concentrations of the five fractions (D2-D6) at $24 \mathrm{~h}$. Data are presented as mean \pm SEM ( $\mathrm{n}=5$ per group). Level of significance was taken at $* \mathrm{p}<0.05$

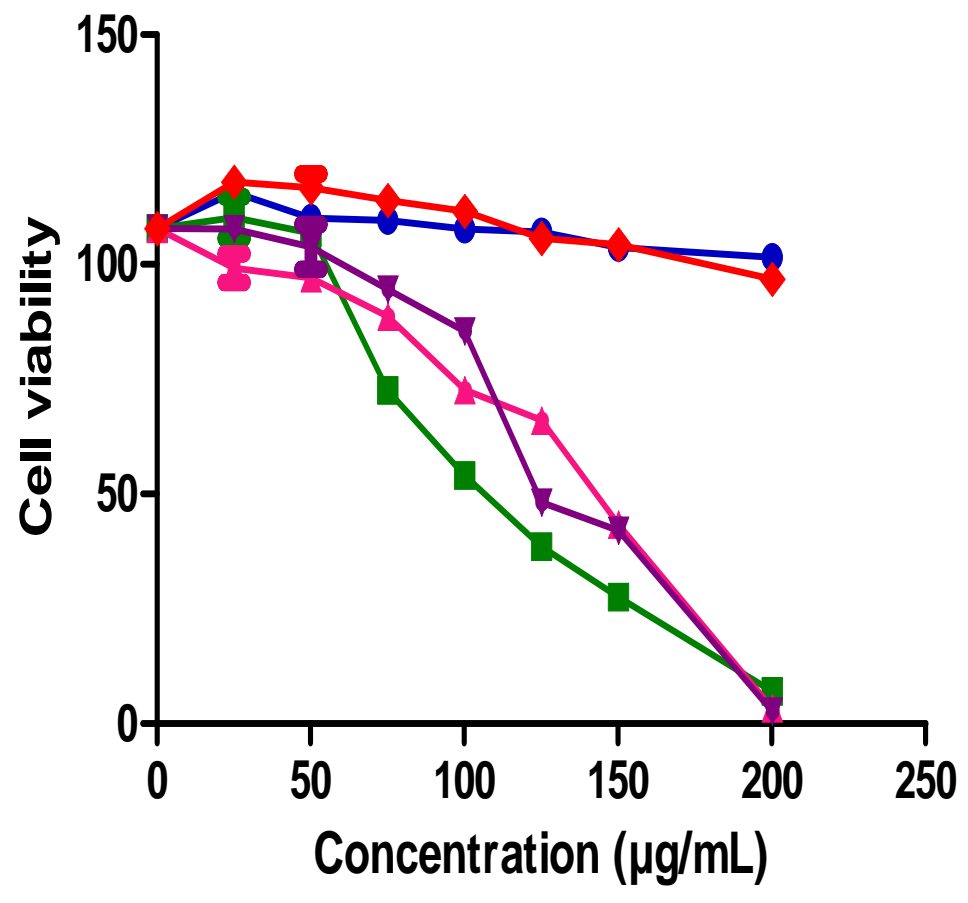

- D2 (butanol fraction)

- D3 (ethyl acetate fraction)

- D4 (n-hexane fraction)

$\checkmark$ D5 (dichlorometane fraction)

- D6 (aqueous fraction) 
Figure 4: The cell viability of HeLa cells at different $(50-200 \mu \mathrm{g} / \mathrm{ml})$ concentrations of the five fractions (D2-D6) at $24 \mathrm{~h}$. Data are presented as mean \pm SEM ( $\mathrm{n}=5$ per group). Level of significance was taken at $* \mathrm{p}<0.05$

\section{Conclusion}

This present work of ours aims at evaluating the cytotoxicity of the plant Momordica charantia on selected cancer cell lines, the crude water-soluble extract was partitioned into five fractions; N-hexane, Dichloromethane, Ethyl acetate, Butanol and Aqeous fractions. We gathered that of all the fractions, D3 was the most potent as it resulted into the least $(<10 \%)$ cell survival after a 24-hour treatment on all the cell lines i.e for MDA-MB $231(<1 \%)$, MDA-MB $436(<1 \%)$, A549 $(5.83 \%)$ and HeLa $(7.01 \%)$ at the optimal tested concentration $(200 \mu \mathrm{g} / \mathrm{ml})$, though D3 and D4 also elicited convincing cytotoxic responses. Further work is underway to elucidate the components of the most potent fraction D3, as well as determine the probable mechanism of action underlying the observed cytotoxicity.

\section{Acknowledgement}

The Authors of this work wish to acknowledge the intellectual and material contributions of OWSD

(Organization for Women in Science for the Developing World) and SIDA (Swedish International

Development Cooperation Agency).

\section{References}

Chen, C. and King A. (2005), "Dietary cancer-chemopreventive compounds: from signaling and gene expression to pharmacological". Trends in Molecular Medicine Vol. 26: Pp. 318-328.

Cheng C. W., Fan W., Ko S. G., Song L. and Bian Z. X. (2010) "Evidence-based management of herbdrug interaction in cancer chemotherapy," Explore, vol. 6, pp. 324-329.

Claflin, A.J., Vesely, D.L., Hudson, J.L. (1978). "Inhibition of growth and guanylate cyclase activity of an undifferentiated prostate adenocarcinoma by an extract of the balsam pear (Momordica charantia abbreviata)". Proc. Nat. Acad. Sci. USA. 75:989-993.

Ehigie, A.F., Ehigie, L.O., Odediran, S.A., Afolabi, O.K., Adedosu, O.T. and Olorunsogo, O.O., (2013). "In vitro Induction of Rat liver Mitochondrial Membrane Permeability Transition Pore Opening by Solvent Extracts of Momordica charantia Leaves". Biokemistri; Vol.25, No.2, Pp. 52-60.

Fang, E.F., Zhang C.Z., Fong W.P. and Ng T.B. (2012), Rnase MC2: "A new Momordica charantia ribonuclease that induces apoptosis in breast cancer cells associated with activation of MAPKs and induction of caspase pathways". Apoptosis Vol. 17, Pp.377-387.

Ferlay J, Soerjomataram I, Ervik M, Dikshit R, Eser S, Mathers C, Rebelo M, Parkin DM, Forman D, Bray, F. (2013). Cancer Incidence and Mortality Worldwide: IARC Cancer Base No. 11 [Internet]. Lyon, France: International Agency for Research on Cancer; 2013. Available from: http://globocan.iarc.fr, accessed on $10 / 1 / 2015$.

Fearon, E.R. and Vogelstein, B. (1990) A genetic model for colorectal tumorigenesis. Cell, 61, 759-767. doi:10.1016/0092-8674(90)90186-I

Jemal, A., Bray F, Center, M. M, Ferlay, J, Ward, E, Forman, D. (February 2011), "Global cancer statistics". CA: a cancer journal for cliniciansVol. 61, No. 2,Pp. 69-90. doi:10.3322/caac.20107PMID 21296855. 
Kandaswami C., Lee L. T. and Lee P. P. (2005).“The antitumor activities of flavonoids,” In Vivo, vol. 19, pp. 895-909.

Kubola, J. and Siriamornpun, S. (2008), "Phenolic contents and antioxidant activities of bitter gourd (Momordica charantia L.) leaf, stem and fruit fraction extracts in vitro”. Food Chemistry, Vol. 110, Pp. 881-890.

Lozano, R; Mohsen, N; Foreman, K; Lim, S; Shibuya, K; Aboyans, V; Abraham, J; Adair, T; Aggarwal, R; Ahn, SY; AlMazroa, MA; Alvarado, M; Anderson, HR; Anderson, LM; Andrews, KG; Atkinson, C; Baddour, LM; Barker-Collo, S; Bartels, DH; Bell, ML; Benjamin, EJ; Bennett, D; Bhalla, K; Bikbov, B; Bin Abdulhak, A; Birbeck, G; Blyth, F; Bolliger, I; Boufous, S; Bucello, C (Dec 15, 2012). "Global and regional mortality from 235 causes of death for 20 age groups in 1990 and 2010: a systematic analysis for the Global Burden of Disease Study 2010". Lancet 380 (9859): 2095-128. doi:10.1016/S0140$\underline{6736(12) 61728-0 .} . \underline{\text { PMID }} \underline{23245604}$

Lee-Huang S., Huang, P.L., Sun, Y. (2000), "Inhibition of MDA-MB-231 human breast tumor xenografts and HER2 expression by anti-tumor agents GAP31 and MAP30". Anti-cancer Res. Vol. 20, Pp. 653-659.

Ng TB, Liu WK, Sze SF and Young HW (1994) "Action of alphamomorcharin, a ribosome inactivation protein on cultured tumor cell lines". General Pharmacology 25: 75-77.

Odewusi, A.F., Oyeyemi, M.O., Olayemi, F.O., Emikpe, B., Ehigie, L.O., Adisa, R.A. and Olorunsogo, O.O., (2010). "Effects of the leaf decoction of Momordica charantia (bitter melon) on mitochondrial membrane permeability transition pore (MPTP) and fertility in normal male albino rats". Afr. J. Med. med. Sci., 39, Suppl. 47-59.

Pitchakarn P., Suzuki S. and Ogawa K. (2011). "Induction of G1 arrest and apoptosis in androgendependent human prostate cancer by Kuguacin J, a triterpenoid from Momordica

charantia leaf," Cancer Letters, vol. 306, no. 2, pp. 142-150.

Ray RB, Raychoudhuri A, Steele R and Nerurkar P (2010) "Bitter Melon (Momordica charantia) extract inhibits breast cancer cell proliferation by modulating cell cycle regulatory genes and promotes apoptosis”. Cancer Research 70: 1925-1931.

Tauseef, A. and Shahabuddin. (2013). "The Uses of Medicinal Plants in the Treatment of Diseases" European Academic Research. I (7): 1850-1853.

Xiong S. D., Yu K. and Liu X. H. (2009) "Ribosome-inactivating proteins isolated from dietary bitter melon induce apoptosis and inhibit histone deacetylase-1 selectively in premalignant and malignant prostate cancer cells," International Journal of Cancer, vol. 125, no. 4, pp. 774-782.

Xu, B.J. and Chang, S.K. (2007). A comparative study on phenolic profiles and antioxidant activities of legumes as affected by extraction solvents. J. Food Sci. 72, S159-166.

Yasui Y., Hosokawa M., Sahara T., Suzuki R., Ohgiya S., Kohno H., Tanaka T. and Miyashita K. (2005). "Bitter Gourd Seed Fatty Acid Rich in 9c,11t,13t-Conjugated Linolenic Acid Induces Apoptosis and UpRegulates the GADD45, p53 and PPAR[gamma] in Human Colon Cancer Caco-2 Cells," Prostaglandins, Leukotrienes and Essential Fatty Acids, 73, (2): 113-119. http://dx.doi.org/10.1016/j.plefa.2005.04.013 